FACTA UNIVERSITATIS

Series: Teaching, Learning and Teacher Education Vol. 3, N ${ }^{\circ}$ 2, 2019, pp. 95 - 107

https://doi.org/10.22190/FUTLTE1902095O

Original research paper

\title{
ANALYSIS OF MOTIVATIONAL FACTORS AND THE PERFORMANCE OF ACADEMIC STAFF OF HIGHER INSTITUTIONS IN KOGI STATE
}

\author{
UDC 378.1:331.1(669.1);331.4:338.312; 159.947.5
}

\author{
Juwon Johnson Orugun ${ }^{1}$, Nurudeen Yakubu Zakariya ${ }^{1}$, \\ Akeem Tunde Nafiu ${ }^{2}$ \\ ${ }^{1}$ Faculty of Management Sciences, Department of Business Administration, \\ Kogi State University, Anyigba, Nigeria \\ ${ }^{2}$ Faculty of Management Sciences, Centre for Predegree and Diploma Studies, \\ Kogi State University, Anyigba, Nigeria
}

\begin{abstract}
This study analyzed motivational factors and the academic staff performance of the higher institutions of learning in Kogi State, Nigeria.. Purposive sampling was used to select two hundred and seventy-eight (278) respondents. The Instrument used was purposefully constructed for this study. Motivational factors were measured with regular pay, work conditions, achievement and job security. Findings show that regular pay, work conditions, achievement and job security have significant predicting power over the teaching quality of the academic staff of the selected higher institutions of learning in Kogi State. The study concluded that regular payment of full salary can facilitate better performance on the part of the academic staff members. The study recommended that the government and the management of the higher institutions of learning in Kogi State should pay more attention to regular pay, work conditions and achievement of their academic staff; and pay less attention on their job security.
\end{abstract}

Key words: Regular Pay, Work Conditions, Job Security, Teaching Quality, Performance, Motivation

\section{INTRODUCTION}

The issue of low morale is likely to be of high concern to the academic staff of the higher institutions of learning in Kogi State. The study of Millett (2010) showed that low morale causes destruction to employees' commitment, and adversely affects the service

Received October 16, 2019/Accepted November 29, 2019

Corresponding author: Juwon Johnson Orugun

Department of Business Administration, Kogi State University, Anvigba, Kogi State Nigeria, P.M.B 1008.

Phone: +23480 64779606•E-mail: orugunjuwonjohnson@gmail.com 
they render. The performance of the academic staff (in terms of teaching quality and contribution to human development goal) may be affected by low morale. Irregular salary payment by the government may be associated with low morale and performance of academic staff of the higher institutions. Lawal, Mustapha, Abogunrin and Yusuf (2019, 43) expressed that "delayed salary payments often results to job boycott whose multiplier effect is low performance". The academic staff members are not working for their institutions without expressed or implicit objectives which must be achieved on mutual understanding. Guru (2010) asserted that members of the academic staff join the institution with different needs and expectations which are influenced by their beliefs, background, lifestyles, perception and attitude. The government may facilitate the achievement of human developmental goal and teaching quality of the academic staff by supporting the achievement of their objectives.

Although, the dominant motivational problem in higher institution borders around irregular pay, some other motivational factors (such as work conditions, achievement, job security, etc.) are critical issues which also need immediate attention in the higher institutions of learning in Kogi State. These are intrinsic factors that have often led to low morale, low level of job satisfaction and absenteeism among the academic staff of the higher institutions of learning in Kogi State. Naharuddin and Sadegi (2013) added that peoples working under inconvenient conditions may end up with low performance and face occupational health risks causing high absenteeism. In his view, Chandrasekar (2011) expressed that job and work environment stimuli affect individual workers on a daily basis. This study expects that the academic staff of the higher institutions of learning in Kogi State become de-motivated also where there is no work condition, achievement and job security. Job security in the higher institutions of learning is associated with the uncertain outcome of ending screening in Kogi State. Regular pay, good work conditions, achievement and job security are motivational factors that can predict academic staff performance. Studies on motivational factors and academic staff performance of the higher institutions in Kogi appear too scanty. This study therefore bridged this gap.

\section{REVIEW OF RELATED LITERATURE}

The controversy regarding financial and non-financial motivation is observed ongoing. The fact remains that financial and non-financial factors can drive behaviour to take a particular shape. According to Armstrong (2009), motivation is about how behavior is initiated by needs and by expectations on the achievement of goals which will satisfy those needs, how the achievement of goals and/or feedback on their achievement reinforces successful behavior and how belief in one's ability to carry out a specific task will actuate behavior which is expected to achieve the successful performance of that task. In line with this, Lawal et al. (2019) noted that the primary reason why people work in the higher institutions of learning in Kogi State is to earn salary that can promote the survival of their households. Bardot (2014) presented a definition of salary as a fixed periodical payment for non-manual academic staff usually expressed in annual terms, paid per month with generally no additions for service rendered. Surbhi (2015) also defined salary as a fixed amount paid to the employees at regular intervals for their performance. Sule and Amuni (2014) re-emphasized the importance of timely/prompt payment of reasonable salaries. The predictability of the academic staff's performance of the higher 
institutions of learning in Kogi State needs to be accurate to a reasonable extent. Sule and Amuni (2014) added that there must be a relative uniformity in the mode and manner such salaries and wages will be paid to the workers.

However, the apparent inappropriate behaviour exhibited by the academic staff of the higher institutions of learning in Kogi State is driven by irregular payment of salary and unending screening, and these appear to have changed the direction and persistence of academic staff in their performance. Meanwhile, reverse appears to be the case in the Federal Higher Institutions of Learning. Though not too specific, Mullin (2005) had mentioned it that this is one of the forces that affects direction, intensity and persistence of voluntary behavior. Salary is one of the factors that motivate the academic staff of the higher institutions of learning in Kogi State to have a changed behavioural pattern as observed today. Mullin (2005) added that when they are willing to exert a particular level of effort (intensity), for a certain amount of time (persistence) toward a particular goal or direction; they are highly motivated. The problem with salary payment in Kogi State as a whole is connected with some factors such as non-appreciable workforce value, political issue, tribal sentiment and leadership inconsideration about the welfare of the masses. These factors among others appear to affect direction, intensity and persistence of voluntary behavior among the academic staff. Based on the welfare of the masses, Chukwudi, Odogwu and Adedehinbo (2012) opined that factors such as the cost of living, ability to pay and capability to pay must be considered in fixing salaries. Apart from salary, other financial benefits are also instrumental to the changing behavioural pattern of the academic staff of the higher institutions of learning in Kogi State.

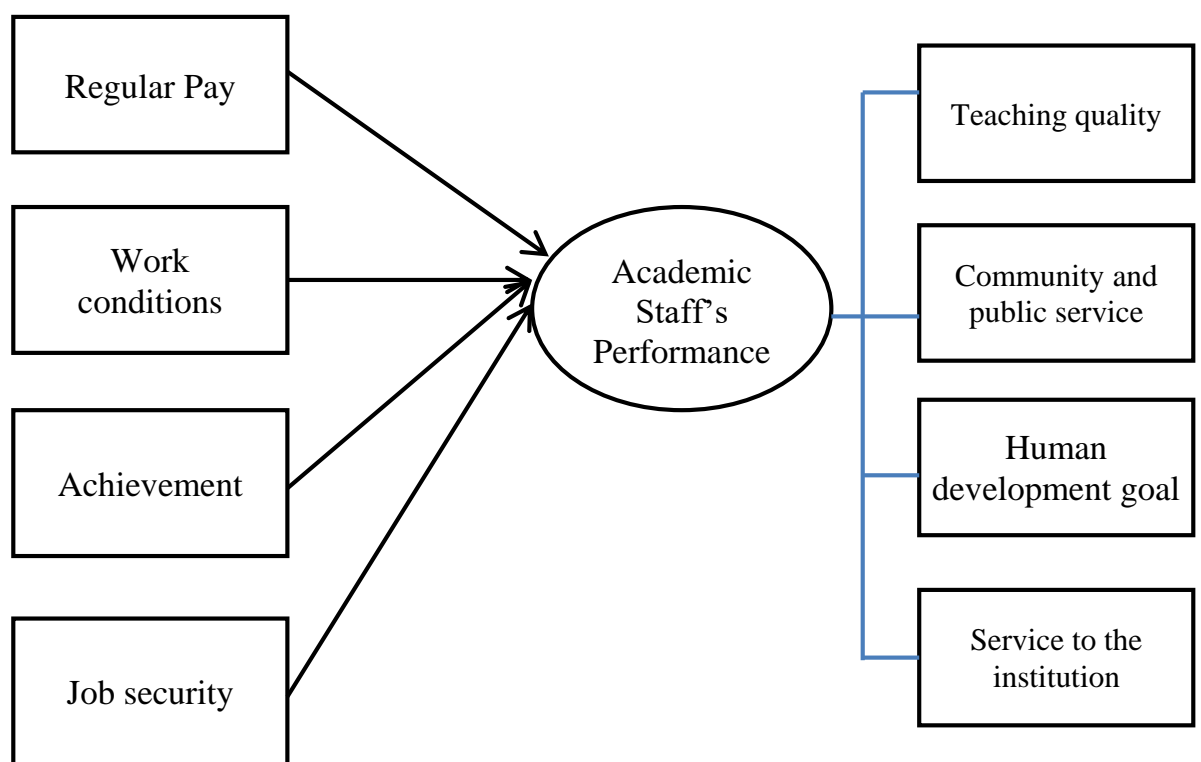

Fig 1 Conceptual Framework

Source: Adopted from Armstrong (2006) cited in Osabiya (2015); Fard, Ghatari and Hasiri (2010); Thomas (2012); Akinfolarin (2013) 
In this study, salary payment is considered as the independent variable and the academic staff performance of the higher institutions of learning in Kogi State is taken as the dependent variable. Ojeleye (2017) also proxied performance as dependent variable, and remuneration (salary/wages, bonus/incentives) as the independent variable. Figure 1 shows that both non-financial rewards and financial rewards have an effect on performance which is yet to be proven negative or positive. Ojeleye (2017) regarded financial aspect of motivation as salaries, wages, bonuses, incentives, allowances and benefits that is accrued or given to the academic staff by the government/ higher institutions of learning in Kogi State as their commitment or reward for employment. The non-financial aspect of motivation may be work conditions, challenging work, career advancement and promotion. Bellè and Cantarelli (2010) added that effective implementation of monetary incentives depends on the relative strengths of the two opposite effects. This actually implies that none of the two is capable of existing in isolation without the other. The lopsided research outcome regarding whether non-financial rewards and financial rewards is an indication of economic differences across international boundaries. The present economic recession in Nigeria may force financial rewards into being the best motivational approach. Academic staff of the higher institutions of learning in Kogi State may appreciate monetary incentives as it cushions the economic hardship in their individual households.

The association between motivation and performance has been studied in the past (Vroom, 1964). In their study, Mwangi (2014) found that with respect to the response on pay for performance system, team work and team reward was positively high. Kamalian et al. (2010) argued that motivation boosts performance. Luis, Gomez, David and Robert (2012) states that most members of the academic staff believe that they should be rewarded to recognize their performance. Negash, Zewude and Megersa (2014) also expressed that compensation (salary) leads to better performance and keeps workers focused on their jobs.

The Herzberg theory indicates that rewards are a medium of expressing satisfactory and unsatisfactory performance. Employees get a symbolic thumb up for better performance when he/she is paid. In practice, many employees who are satisfactory or better maybe demotivated by schemes which do not benefit them (Chaudhary and Sharma, 2012).

Different scholars (Hassna and Raza, 2011; Mawoli and Babandako, 2011; Ologunde, Akindele and Akande, 2013; Tinuke, 2015; Cadez, Dimovski, and Groff, 2017) have analysed performance of academic staff. Astin and Lee (1967) found out that classroom teaching and research were given equally high weight in assessing faculty performance. Cadez et al. (2017) revealed that academic performance was not related to teaching quality, whereas research quality was positively related with teaching quality. Centra (1977) reported that in research universities, with large Ph.D. programs and heavy financial support for research, research was the most important activity for the faculty and teaching was second in importance. Community and public service, student advising and service to the institution were considered to be relatively minor activities. Ghannam (2007) reported that integration of teaching and research with community service was necessary for the advancement of society. Hassna and Raza (2011) found a significant positive relation between the faculty teaching and service performances. However, there was no support to establish significant relationship between the scholarly endeavour with either teaching or service performance. 


\section{RESEARCH METHODOLOGY}

The main objective of the study was to investigate the effect of motivational factors on the academic staff performance of the higher institutions of learning in Kogi State, Nigeria. The specific objectives of the study were to:

i. Determine the extent to which there is a linear relationship between the teaching quality of the academic staff of the higher institutions of learning in Kogi State and motivational factors (regular pay, work conditions, achievement and job security).

ii. Ascertain the relationship between regular pay, work conditions, achievement, job security, teaching quality, community and public service and contribution to human development goal in the higher institutions of learning in Kogi State.

\subsection{Sample and procedure}

The population of the study comprised of academic staff members in the higher institutions of Kogi State. Purposive sampling was used to select two hundred and seventyeight (278) respondents. 278 questionnaires (100\%) were administered; 268 questionnaires $(96.40 \%)$ were returned while 10 questionnaires $(3.60 \%)$ were not returned. Based on the result, the study analyzed data on the returned questionnaires. 129 respondents $(46.9 \%)$ were male and 146 respondents $(53.1 \%)$ were female.

\subsection{Instrument}

The instrument used for data collection was closed ended questionnaires (well structured). Motivational factors are measured with regular pay, work conditions, achievement and job security. The performance of the academic staff is proxied with teaching quality. The instrument was validated through a trial test using the questionnaire on twenty (20) respondents. The understanding of the respondents regarding the subject matter was investigated. The trial test led to readjustment of the instrument to elicit quality data collection. The study used the Cronbach alpha process to establish the reliability of the instrument. The reliability of the instrument was 72.5 .

\subsection{Methods of Data Analysis}

Data collected were analyzed using descriptive statistics, multiple regression and correlation matrix. The descriptive statistics was used to describe the strength of the variables (teaching quality, commitment to community and public service, contribution to human development goal, job security, regular pay, work conditions and achievement). Multiple regression was used to predict the linear relationship between the motivational factors and academic staff performance. Correlation matrix was used to establish the relationship between regular pay, work conditions, achievement, job security, teaching quality, community and public service and contribution to human development goal in the higher institutions of learning. 


\section{DATA ANALYSIS AND RESULTS}

Table 1 show the results of the effects of regular pay, work conditions, achievement and job security on the teaching quality of the academic staff of the higher institutions of learning in Kogi State.

Table 1 Regression models on the effects of motivational factors on the academic staff performance of the higher institutions of learning in Kogi State

\begin{tabular}{lccc}
\hline Variables & Coefficients & Estimate of Std. Error & P-value \\
\hline Regular Pay & -.583 & .079 & .000 \\
Work Conditions & .278 & .115 & .001 \\
Achievement & .408 & .121 & .000 \\
Job Security & .193 & .145 & .185 \\
\hline Multiple R & & .814 & \\
R Square & & .663 & \\
Adjusted R Square & & .654 & \\
F-Stat & & 73.182 & \\
Sig. & & .000 & \\
\hline \multicolumn{2}{c}{ Source: Field survey, 2019. }
\end{tabular}

The Multiple Quotient of Determination $(\mathrm{R}=0.814)$ in table 1 indicates strong linear relationship between the variables. The quotient of determination $\left(R^{2}=0.663\right)$ shows the spread of data on the regression line. The R-square indicates that $66.3 \%$ variation in the teaching quality of the academic staff of the higher institutions of learning in Kogi State is explained by the predictor variables (such as regular pay, work conditions, achievement and job security). The remaining $33.7 \%$ shows that there are other variables that account for variations in the teaching quality of the academic staff of the higher institutions of learning in Kogi State.

Table 1 shows the relationships between each of the independent variables and the teaching quality of the academic staff of the higher institutions of learning in Kogi State. Regular pay in the regression model is -0.583 with the p-value of equal to 0.01 . This quotient represents the mean increase in the teaching quality of the academic staff for every decrease in regular pay. Interestingly, $48.0 \%$ increase in the teaching quality of the academic staff is significantly brought about by proportional decrease in regular pay. Work conditions in the regression model are 0.278 with the p-value equal to 0.01 . Also, the quotient represents the mean increase in the teaching quality of the academic staff of the higher institutions of learning in Kogi State for every persisting increase in work conditions. The implication of this is that $27.8 \%$ change in work conditions will bring about proportional positive change in the teaching quality of the academic staff of the higher institutions of learning in Kogi State. The achievement of the academic staff members in the regression model is 0.408 . This quotient represents the mean increase in the teaching quality of the academic staff of the higher institutions of learning in Kogi State for every increase in achievement of the academic staff members. Interestingly, $40.8 \%$ increase in the teaching quality of the academic staff of the higher institutions of learning in Kogi State is a result of the proportional increase in the achievement of the academic staff members. Job security in the regression model is 0.193 . This quotient represents the mean increase in the teaching quality of the academic staff of the higher institutions of learning in Kogi State for every increase guarantee in the job security of the academic staff members. Interestingly, 
$19.3 \%$ change in the teaching quality of the academic staff of the higher institutions of learning in Kogi State is a result of the proportional change in the job security of the academic staff members; but this appears to be insignificant.

Table 2a Descriptive Statistics of variables

\begin{tabular}{lccc}
\hline Variables & Mean & Std. Deviation & $\mathrm{N}$ \\
\hline Teaching Quality & 2.7090 & 1.26209 & 268 \\
Commitment to community and public service & 3.4478 & 1.17443 & 268 \\
Contribution to human development goal & 3.5000 & 1.21322 & 268 \\
Job Security & 2.9478 & 1.37019 & 268 \\
Regular Pay & 3.6493 & 1.17245 & 268 \\
Work conditions & 2.5261 & 1.34473 & 268 \\
Achievement & 3.5373 & 1.23408 & 268 \\
\hline
\end{tabular}

Source: Field survey, 2019.

Table $2 \mathrm{a}$ shows the descriptive statistics of regular pay (mean= 3.6493; standard deviation $=1.17245)$, work conditions $($ mean $=2.5261$; standard deviation $=1.34473)$, achievement of academic staff members (mean $=3.5373$; standard deviation $=1.23408$ ), job security $($ mean $=2.9478$; standard deviation $=1.37019)$, teaching quality (mean= 2.7090; standard deviation=1.26209), contribution to community and public service $($ mean $=3.4478$; standard deviation $=1.17443)$ and human development goal (mean= 3.5000; standard deviation $=1.21322$ ) of the higher institutions of learning in Kogi State.

Table 2b Correlations matrix of variables

\begin{tabular}{lllllllll}
\hline Variables & TQY & CPS & HDG & JSY & RGP & WCD & AVT \\
\hline TQY & Pearson Correlation & 1 & $-.432^{* *}$ & $-.379^{* *}$ & -.033 & $-.469^{* *}$ & $.417^{* *}$ & $-.245^{* *}$ \\
& Sig. (2-tailed) & & .000 & .000 & .595 & .000 & .000 & .000 \\
& N & 268 & 268 & 268 & 268 & 268 & 268 & 268 \\
CPS & Pearson Correlation & $-.432^{* * *}$ & 1 & $.292^{* * *}$ & .045 & $.218^{* *}$ & $-.261^{* *}$ & $.169^{* *}$ \\
& Sig. (2-tailed) & .000 & & .000 & .465 & .000 & .000 & .005 \\
& N & 268 & 268 & 268 & 268 & 268 & 268 & 268 \\
HDG & Pearson Correlation & $-.379^{* *}$ & $.292^{* *}$ & 1 & -.047 & $.779^{* *}$ & $-.561^{* *}$ & $.660^{* *}$ \\
& Sig. (2-tailed) & .000 & .000 & & .440 & .000 & .000 & .000 \\
& N & 268 & 268 & 268 & 268 & 268 & 268 & 268 \\
JSY & Pearson Correlation & -.033 & .045 & -.047 & 1 & .063 & -.099 & -.001 \\
& Sig. (2-tailed) & .595 & .465 & .440 & & .303 & .106 & .986 \\
& N & 268 & 268 & 268 & 268 & 268 & 268 & 268 \\
RGP & Pearson Correlation & $-.469^{* * *}$ & $.218^{* *}$ & $.779^{* *}$ & .063 & 1 & $-.438^{* *}$ & $.540^{* *}$ \\
& Sig. (2-tailed) & .000 & .000 & .000 & .303 & & .000 & .000 \\
& N & 268 & 268 & 268 & 268 & 268 & 268 & 268 \\
WCD & Pearson Correlation & $.417^{* * *}$ & $-.261^{* *}$ & $-.561^{* *}$ & -.099 & $-.438^{* *}$ & 1 & $-.715^{* *}$ \\
& Sig. (2-tailed) & .000 & .000 & .000 & .106 & .000 & & .000 \\
& N & 268 & 268 & 268 & 268 & 268 & 268 & 268 \\
AVT & Pearson Correlation & $-.245^{* *}$ & $.169^{* *}$ & $.660^{* *}$ & -.001 & $.540^{* *}$ & $-.715^{* *}$ & 1 \\
& Sig. (2-tailed) & .000 & .005 & .000 & .986 & .000 & .000 & \\
& N & 268 & 268 & 268 & 268 & 268 & 268 & 268 \\
\hline
\end{tabular}

. Correlation is significant at the 0.01 level (2-tailed).

Note: Regular Pay- RGP, Work Conditions- WCD, Achievement-AVT, Job Security- JSY, Teaching QualityTQY, Community and Public Service- CPS, and Contribution to Human Development Goal- HDG. 
Table 2b shows the relationship among variables such as Regular Pay, Work Conditions, Achievement of the Academic Staff members, Job Security, Teaching Quality, Community and Public Service and Contribution to Human Development Goal.

It is depicted that Teaching Quality has significant relationship with Community and Public Service $(\beta=-.432$; $p$-value= 0.01), Human Development Goal $(\beta=-.379$; $p$-value= $0.01)$, Regular Pay $(\beta=-.469 ; p$-value $=0.01)$, Work Conditions $(\beta=.417 ; p$-value $=0.01)$ and Achievement of the Academic Staff members $(\beta=-.245$; $p$-value $=0.01)$. It is observed that Teaching Quality has significant positive relationship with only Work Conditions. This implies that the Work Conditions of the selected institutions influence the Teaching Quality in the institutions. Teaching Quality is likely to be boosted by $41.7 \%$ if the Work Conditions of the selected institutions become more favourable by $41.7 \%$. Meanwhile, teaching quality is likely to decrease by $43.2 \%$ if the contribution of academic staff to the community and public service increases by $43.2 \%$; teaching quality is likely to decrease by $37.9 \%$ if the contribution of academic staff to human development goal increases by $37.9 \%$; teaching quality is likely to decrease by $46.9 \%$ if the regular payment of salaries is ensured by $46.9 \%$; and teaching quality is likely to decrease by $24.5 \%$ if the achievement of the academic staff increases by $24.5 \%$.

Table $2 \mathrm{~b}$ shows that Community and Public Service has significant relationship with Human Development Goal $(\beta=.292 ; \mathrm{p}$-value $=0.01)$, Regular Pay $(\beta=.218$; $p$-value= 0.01), Work Conditions $(\beta=-.261$; $p$-value $=0.01)$ and Achievement $(\beta=.169$; $p$-value $=0.01)$. It is observed that contribution of the academic staff members to community and public service has significant negative relationship with only work conditions. This implies that increase in the contribution of the academic staff members to community and public service by $26.1 \%$ is a result of decrease in the work conditions in the selected institutions. Contribution of the academic staff members to community and public service has positive relationship with the contribution of the academic staff members to human development goal, regular pay and the achievement of the academic staff members. Contribution of the academic staff members to community and public service is likely to increase by $29.2 \%$ if the contribution of the academic staff members to human development goal increases by $29.2 \%$; Contribution of the academic staff members to community and public service is likely to increase by $21.8 \%$ if regular pay increases by $21.8 \%$; and Contribution of the academic staff members to community and public service is likely to increase by $16.9 \%$ if the achievement of the academic staff members increases by $16.9 \%$.

Table $2 b$ shows that Human Development Goal has significant relationship with Regular Pay $(\beta=.779 ; p$-value $=0.01)$, Work Conditions $(\beta=-.561 ; p$-value $=0.01)$ and Achievement $(\beta=.660 ; p$-value $=0.01)$. It is observed that the contribution of the academic staff members to human development goal has significant negative relationship with only work conditions. This means that decrease in the contribution of the academic staff members to human development goal by $56.1 \%$ will lead to increase in the work conditions of the selected institutions by $56.1 \%$. Meanwhile, the contribution of the academic staff members to human development goal has significant positive relationship with regular pay and the achievement of the academic staff members. By implication, $77.9 \%$ increase in the contribution of the academic staff members to human development goal is likely to be influenced by $77.9 \%$ increase in regular pay; and $66.0 \%$ increase in the contribution of the academic staff members to human development goal is likely to be influenced by $66.0 \%$ increase in the achievement of the academic staff members of the selected institutions. 
Table $2 b$ shows that regular pay has significant relationship with work conditions $(\beta=$ $-.438 ; \mathrm{p}$-value $=0.01)$ and achievement $(\beta=.540 ; \mathrm{p}$-value $=0.01)$. The result from the table shows that regular pay has significant negative relationship with work conditions. This means that $43.8 \%$ decrease in regular pay is likely to be influenced by $43.8 \%$ increase in work conditions. On the other hand, the table shows that regular pay has significant positive relationship with the achievement of the academic staff members of the selected institutions. The implication of this is that $54.0 \%$ increase in regular pay is likely to bring about $54.0 \%$ increases in the achievement of the academic staff members of the selected institutions. The result from the table also shows that work conditions have significant negative relationship with the achievement of the academic staff members of the selected institutions $(\beta=-.715$; $p$-value $=0.01)$. This means that $71.5 \%$ change in work conditions of academic staff will bring about $71.5 \%$ inverse changes in the academic staff members of the selected institutions. Job security has no significant relationship with regular pay, work conditions, achievement, teaching quality, community and public service and contribution to human development goal.

\section{DISCUSSION OF FINDINGS}

Findings show that variables such as regular pay, work conditions, achievement and job security have significant predicting power over the teaching quality of the academic staff of the selected higher institutions of learning in Kogi State. This aligns with the finding of Akinfolarin and Ehinola (2014) motivational factors significantly affect lecturers' teaching and research activities. For instance, empirical investigation proves that increase in the teaching quality of the academic staff is a result of the decrease in regular pay. This may occur as a result of the percentage payment of salaries in Kogi State. It is natural of the academic staff to exhibit a level of de-motivation particularly when they are short-changed in their expected salaries.

Work conditions influence the teaching quality of the academic staff of the higher institutions of learning in Kogi State. The degree of the influence appears to be low given the $27.8 \%$ change in work conditions. The fact remains that change in work conditions leads to the same change in the teaching quality of the academic staff of the higher institutions of learning in Kogi State. This is supported by the study of Jayaweera (2015) and Ali, Dahie and Ali (2016) which found a significant association between work conditions and performance of academic staff. In addition, increase in the achievement of the academic staff members will lead to increase in the teaching quality of the academic staff of the higher institutions of learning in Kogi State; and the influence of job security on the teaching quality of the academic staff of the higher institutions of learning in Kogi State appears to be too weak. These findings prove the assertion of Guru (2010) that members of the academic staff join the institution with different need and expectations which are influenced by their perception and attitude. In fact, the relationship between job security and the teaching quality of the academic staff of the higher institutions of learning in Kogi State is insignificant. This finding is against the assertion of Faremi (2017) that job security is a job retention strategy. There will be no need for the higher institutions of learning in Kogi State to job security as job retention strategy since has no significant relationship with the teaching quality of the academic staff. 
Findings show that teaching quality has significant relationship with community and public service, human development goal, regular pay, work conditions and achievement of the academic staff members. It is however established that teaching quality has significant positive relationship with only work conditions. This means that increase in work conditions has the propensity to increase the teaching quality of the academic staff members. The finding of Ali et al. (2016) aligns with the finding of this present study. It was found that teaching quality is likely to decrease where an increase in the contribution of academic staff to the community and public service is evident. If the teaching quality decreased by $37.9 \%$, the contribution of academic staff to human development goal will increase by $37.9 \%$. Teaching quality will decrease by $46.9 \%$ if the regular payment of salaries is ensured by $46.9 \%$. The teaching quality will decrease by $24.5 \%$ if the achievement of the academic staff increased by $24.5 \%$.

Findings show that community and public service has significant relationship with human development goal, regular pay, work conditions and achievement. Contribution of the academic staff members to community and public service has significant negative relationship with work conditions. The implication of this is that the contribution of the academic staff members to community and public service will negatively respond given a change in the work conditions in the selected institutions. Findings also reveal that the contribution of the academic staff members to community and public service has positive relationship with the contribution of the academic staff members to human development goal, regular pay and the achievement of the academic staff members.

Findings show that human development goal has significant relationship with regular pay, work conditions and achievement. Contribution of the academic staff members to human development goal has significant negative relationship with work conditions. The implication of this is that the contribution of the academic staff members to human development goal will drop sharply as effort to enhance more work conditions of the selected institutions increases. Findings also show that the contribution of the academic staff members to human development goal has significant positive relationship with regular pay and the achievement of the academic staff members.

Finally, findings show that regular pay has significant relationship with work conditions and achievement. Empirical investigation proves that regular pay has significant negative relationship with work conditions. The implication of this is that the more regular pay of salaries becomes guaranteed the less the work conditions of the selected higher institutions in Kogi State. These findings show that the issue of salary payment is too critical to the institutions that more focus on regular pay will cause work conditions to reduce. Regular pay has significant positive relationship with the achievement of the academic staff members of the selected institutions. This implies that whenever salaries are paid regularly, opportunities are created for the academic staff to meet their needs. Thus, increase in regular pay will increase in the achievement of the academic staff members of the selected institutions. Findings also show that work conditions has significant negative relationship with the achievement of the academic staff members of the selected institutions, and that job security has no significant relationship with regular pay, work conditions, achievement, teaching quality, community and public service and contribution to human development goal. 


\section{CONCLUSION AND RECOMMENDATIONS}

The motivation of academic staff members of the selected institutions remains highly imperative. It is associated with their performance achievement. Regular pay is a serious motivator for academic staff members in Kogi State. When the academic staff members are regularly paid their actions, willingness and favourable attitude towards achieving the institutional goal will be inspired. The issue of regular payment of salaries in percentages is not likely to inspire the academic staff members' actions, willingness and favourable attitude towards achieving the institutional goal.

Regular payment of full salary can facilitate better performance on the part of the academic staff members. Performance of the academic staff members in Kogi State was decomposed into teaching quality and contribution to human development goal. It was scientifically proven that regular payment of salary has weak effect on the teaching quality of the academic staff of selected institutions in Kogi State. This is because salaries are being paid in percentages to the academic staff of selected institutions in Kogi State. However, it was empirically proven that regular payment of salary has favourable relationship with teaching quality of academic staff. On the other hand, regular payment of salary was found to have significant effect on the contribution of academic staff to the human development goal of the selected institutions. This effect was found strong and positive. Empirically, the relationship between regular payment of salary and contribution of academic staff to the human development goal is confirmed positive.

Regular pay was not only a motivator to the academic staff of the selected higher institutions of learning in Kogi State. The work conditions, achievement and job security in the higher institutions were also motivators. It was empirically confirmed that regular pay, work conditions, achievement and job security significantly predict the teaching quality of the academic staff of the selected higher institutions of learning in Kogi State. Meanwhile, it was ascertained that teaching quality has significant relationship with community and public service, human development goal, regular pay, work conditions and achievement of the academic staff members. Also, community and public service has significant relationship with human development goal, regular pay, work conditions and achievement; as human development goal has significant relationship with regular pay, work conditions and achievement. Findings show that the relationship between regular pay, work conditions and achievement is very significant.

Based on the findings of the study, the following recommendations are made that:

i. The government and the management of the higher institutions of learning in Kogi State should pay more attention to regular pay, work conditions and achievement of their academic staff; and pay less attention on their job security. Regular pay, work conditions and achievement of academic staff have significant effects on their teaching quality.

ii. The relationship between teaching quality and work conditions should be sustained. The higher institution of learning in Kogi State should manage the trade-off between teaching quality and contribution of academic staff to the community and public service. The management of higher institutions should monitor or supervise the teaching activities of their academic staff because they seem to be relieved and pay less attention to work when they achieve their needs. The management of higher institutions should moderate the community and public service of the academic staff members as it has a trade-off with work conditions. Alternatively, the management of higher institutions should encourage contribution of the academic staff members to community and public service to boost contribution to human development goal and fulfillment of the academic staff members. 


\section{REFERENCES}

Akinfolarin, A. V. (2013). Leadership Deficiency: A Cause of Education Crisis in Nigeria. Retrieved on 21/02/2018 from http://myschool.com.ng/school/news/21853/leadership-defficiency-a-cause-of-educationcrisis-in-nigera-akinfolarin.html

Akinfolarin, A. V., and Ehinola, G. B. (2014). Motivation and Effective Performance of Academic Staff in Higher Education (Case Study of Adekunle Ajasin University, Ondo State, Nigeria). International Journal of Innovation and Research in Educational Sciences, 1(2), 157-163.

Ali, A. Y., Dahie, A. M., and Ali, A. A. (2016). Teacher Motivation and School Performance, the Mediating Effect of Job Satisfaction: Survey from Secondary Schools in Mogadishu. International Journal of Education and Social Science, 3(1), 24-38

Armstrong, M. (2006). Human Resource Management Practice. In B.J. Osabiya (eds). The effect of employees' motivation on organizational performance. Journal of Public Administration and Policy Research, 7(4), 62-75.

Armstrong, M. (2009). A handbook of human resource management practice. In: B.M. Mohamedi (eds). Impact Of Employee Motivation On Job Performance In Tanzania Banking Sector: A Case Study Of Tanzania Postal Bank Head Office. A Dissertation, the Open University of Tanzania

Astin, A. W., and Lee, C. B. T. (1967). Current practices in the evaluation and training of college teachers. Washington, D.C: American Council on Education.

Bardot, S. (2014). What is the difference between a bonus and an incentive? Retrieved on 25/12/2017 from http://compensationinsider.com/what-is-the-difference-between-a-bonus-and-an-incentive/

Bellè, N., and Cantarelli, P. (2010). Public Service Motivation: The State of the Art. Paper prepared for the Conference "Reforming the Public Sector: How to make the Difference?" December 2-3, 2010, Rome Italy.

Cadez, S., Dimovski, V., and Groff, M. Z. (2017). Research, teaching and performance evaluation in academia: the salience of quality. Studies in Higher Education, 42(8), 1455-1473.

Centra, J. A. (1977). How universities evaluate faculty performance: A survey of department heads. Educational Testing Service, 12(1), 3-25.

Chandrasekar, K. (2011). Workplace environment and its impact on organisational performance in public sector organizations. International Journal of Enterprise Computing and Business Systems, 1(1), 1-16.

Chaudhary, N., \& Sharma, B. (2012). Impact of employee motivation on performance (productivity) private organization. International Journal of Business Trends and Technology, 2(1), 29-35.

Chukwudi, F. A., Odogwu, C. C., and Adedehinbo, E. B. (2012). Motivation and employees performance in the public and private sector in Nigeria. In: O. E. Sule and S. I. Amuni (2014). Wages and Salaries Administration as Motivational Tool in Nigerian Organisation (A Case Study of Nestle Nigeria PLC). Journal of Business Theory and Practice. 2(2), 247-266. Retrieved on 23/04/2018 from www.scholink.org/ojs/index.php/jbtp

Fard, H. D., Ghatari, A. R., \& Hasiri, A. (2010). Employees Morale in Public Sector: Is Organizational Trust an Important Factor?. European Journal of Scientific research, 46(3), 378-390.

Faremi, M. F. (2017). An Assessment of Teacher Retention and Job Security in Private Secondary Schools in Ogun State, Nigeria. Bulgarian Journal of Science and Education Policy, 11(2), 279-293.

Ghannam, M. T. (2007). Integration of teaching and research with community service for engineering programs. European Journal of Engineering Education, 32(2), 227-235.

Guru, N. A. (2010). Impact of Motivation on Employee Performance at Nationlink Telecom. Somalia. In: B.M. Mohamedi (eds). Impact Of Employee Motivation On Job Performance In Tanzania Banking Sector: A Case Study Of Tanzania Postal Bank Head Office. A Dissertation, the Open University of Tanzania

Hassna, L. O., and Raza, S. (2011). An assessment of the relationship between the faculty performances in teaching, scholarly endeavour, and service at Qatar University. Research in Higher Education Journal, $10(1), 1-18$

Herzberg, F., Mausner, B., and Snyderman, B. B. (1959). The motivation to work. New York: John Wiley \& Sons.

Jayaweera, T. (2015). Impact of Work Environmental Factors on Job Performance, Mediating Role of Work Motivation: A Study of Hotel Sector in England. International Journal of Business and Management, 10(3), 271-278.

Kamalian, A. R., Yaghoubi, N. M., \& Moloudi, J. (2010). Survey of Relationship between Organizational Justice and Empowerment (A Case Study). European Journal of Economics, Finance and Administrative Sciences, 24(1), 165-171

Lawal, A. T., Mustapha, A. M., Abogunrin, A. P., and Yusuf, S. (2019). Assessment of Teachers' Motivation and Job Satisfaction for School Performance in Kogi State, Nigeria. Entrepreneurial Journal of Management Sciences, 6(1), 41-57. 
Luis, R., Gomez, M., David, B., and Robert, L. (2012). Managing Human Resources. In P.K. Mwangi (eds.). The Effect of Compensation on Employee Motivation: A Case Study of Chloride Exide. A Project Report: United States International University.

Mawoli, M. A., and Babandako, A. Y. (2011). An evaluation of staff motivation, dissatisfaction and job performance in an academic setting. Australian Journal of Business and Management Research. 1(9): 1-13.

Millett, T. (2010). 6 reasons why staff morale is important. In H.C. Ngambi (eds). The relationship between leadership and employee morale in higher education. African Journal of Business Management, 5(3), 762776. DOI: 10.5897/AJBM10.854

Mwangi, P. K. (2014). The Effect of Compensation on Employee Motivation: A Case Study of Chloride Exide. A Project Report: United States International University.

Naharuddin, N. M., \& Sadegi, M. (2013). Factors of workplace environment that affect employees performance: A case study of Miyazu Malaysia. International Journal of Independent Research and Studies, 2(1), 66-78.

Negash, R., Zewude, S., and Megersa, R. (2014). The effect of compensation on employees' motivation: In Jimma University academic staff. Basic Research Journal of Business Management and Accounts, 3(2), 1727. Retrieved on 26/01/2018 http//www.basicresearchjournals.org

Ojeleye, Y. C. (2017). The Impact of Remuneration on Employees' Performance (A Study of Abdul Gusau Polytechnic, Talata-Mafara and State College Of Education Maru, Zamfara State). Arabian Journal of Business and Management Review, 4(2), 34-43. Retrieved on 25/02/2018 from www.arabianjbmr.com

Ologunde, A. O., Akindele, R. I., and Akande, W. O. (2013). Moonlighting among university lecturers and their performance in the South-Western Nigeria. Journal of Management and Sustainability, 3(4), 92-102.

Osabiya, B. J. (2015). The effect of employees' motivation on organizational performance. Journal of Public Administration and Policy Research, 7(4), 62-75.

Sule, O. E., and Amuni, S. I. (2014). Wages and Salaries Administration as Motivational Tool in Nigerian Organisation (A Case Study of Nestle Nigeria PLC). Journal of Business Theory and Practice, 2(2), 247266. Retrieved on 23/04/2018 from www.scholink.org/ojs/index.php/jbtp

Surbhi, S. (2015). Differences between Salaries and Wages. Retrieved on 24/12/2017 from http://keydifferences. com/difference-between-salary-and-wages.html\#ixzz4IG1CT6Vu

Thomas, O. (2012). Effects of Motivation on Employee Performance in Ghana Commercial Bank Zone. In: B.M. Mohamedi (eds). Impact Of Employee Motivation On Job Performance In Tanzania Banking Sector: A Case Study Of Tanzania Postal Bank Head Office. A Dissertation, the Open University of Tanzania

Tinuke, F. M. (2015). Dimensions of university academic staff performance appraisal in selected public universities in Nigeria. Journal of Global Economics, Management and Business Research, 3(3), 139-147.

\section{ANALIZA MOTIVACIONIH FAKTORA I PERFORMANSI AKADEMSKOG OSOBLJA INSTITUCIJA VISOKOG OBRAZOVANJA U DRŽAVI KOGI}

U radu se analiziraju motivacioni faktori i performanse akademskog osoblja $u$ institucijama visokog obrazovanja u državi Kogi, Nigerija. Kao namerni uzorak izabrano je 278 ispitanika. Korišćeni instrument, konstruisan je namenski za svrhe ovog istraživanja. Dobijeni rezultati istraživanja pokazali su da su redovna plata, uslovi rada, postignuće i sigurnost na poslu značajni prediktori kvaliteta nastave akademskog osoblja izabranih institucija visokog obrazovanja u državi Kogi. U skladu sa tim zaključeno je da redovna isplata zarade može olakšati bolje izvođenje dela članova akademskog osoblja. U tom smislu preporuka je da vlada $i$ oni koji upravljaju institucijama visokog obrazovanja $u$ državi Kogi treba da obrate više pažnje na redovne plate, uslove rada i postignuća akademskog osoblja, a manje na njihovu sigurnost na poslu.

Ključne reči: redovna plata, uslovi rada, sigurnost na poslu, kvalitet nastave, performance, motivacija 